Proceedings

\title{
Identification and Characterization of Metabolic Potential of Different Strains from Genus Rhizobium $^{\dagger}$
}

\author{
Karolina Gawryjołek ${ }^{1}$, Karolina Furtak ${ }^{1,}{ }^{*}$, Jarosław Grządziel ${ }^{1}$ and Anna Gałązka ${ }^{1}$ \\ 1 Department of Agricultural Microbiology, Institute of Soil Science and Plant Cultivation State Research \\ Institute, Czartoryskich 8, Puławy, Poland; kgaw@iung.pulawy.pl; kfurtak@iung.pulawy.pl; \\ jgrzadziel@iung.pulawy.pl; agalazka@iung.pulawy.pl \\ * Correspondence:kfurtak@iung.pulawy.pl; Tel.: 81-47-86-961 \\ + Presented at the 1st International Electronic Conference on Microbiology, 2-30 November 2020; Available \\ online: https://ecm2020.sciforum.net/
}

Published: 2 November 2020

\begin{abstract}
Bacteria of the Rhizobium genus form a group of microorganisms existing in the environment in two forms: symbiotic - in the root nodules of Fabaceae sp. plants and free-living, saprophytic in the soil environment. The subject of study was genetic identification and characterization of metabolic activity of different strains from Rhizobium genus bacteria. The study was conducted on the 16 bacteria strains from the collection of Department of Agricultural Microbiology, Institute of Soil Science and Plant Cultivation in Puławy, Poland. Based on the sequencing of PCR products, we found that all strains belong to one species - Rhizobium leguminosarum. The study of metabolic activity was performed using the GEN III BIOLOG system method (Biolog Inc., Hayward, CA, USA). Metabolism analysis of all R. leguminosarum strains with the use of GEN III ${ }^{\mathrm{TM}}$ plates showed that carbohydrates $(\mathrm{CH})$ were the most intensively utilised group of substrates. Between the Rhizobium leguminosarum strains, there are metabolic differences in terms of the studied features.
\end{abstract}

Keywords: bacterial strain; Rhizobium; Biolog GEN III

\section{Introduction}

Bacteria of the Rhizobium genus form a group of microorganisms existing in the environment in two forms: symbiotic - in the root nodules of Fabaceae sp. plants and free-living, saprophytic in the soil environment [1]. Inside of root this bacteria differentiation into nitrogen-fixing bacteroids [2]. The basic function of Rhizobium sp. in a symbiosis is to reduce nitrogen to ammonia directly assimilated by the plant. Nitrogen reduction occurs with the participation of enzymatic nitrogenase complex [3]. The subject of study was genetic identification and characterization of metabolic activity of different strains from Rhizobium genus.

\section{Material and methods}

\subsection{Bacterial strains}

The study was conducted on the 16 bacteria strains from the collection of Department of Agricultural Microbiology, Institute of Soil Science and Plant Cultivation in Puławy, Poland. Bacteria strains were isolated from root nodules derived from plans of the genus Trifolium. The collection of bacterial strains was obtained from the roots of plants growing in many locations, mainly in Poland (Table 1). 
Table 1. Source of bacterial strains.

\begin{tabular}{cccc}
\hline $\begin{array}{c}\text { Strain } \\
\text { symbol }\end{array}$ & Location & Plant & Year \\
\hline C37 & Poland, Lublin & Trifolium sp. & 1960 \\
209 & USA, Madison & Trifolium sp. & 1960 \\
325a & USSR, Leningrad (now Russia, & Trifolium sp. & 1957 \\
G & Petersburg) & Trifolium sp. & 1994 \\
G4 & Poland, Gnojno & White clover (T. repens L.) & 1995 \\
KB & Poland, Grabów & White clover (T. repens L.) & 1995 \\
KR & Poland, Grabów & Red clover (T. pratense L.), var. & 1996 \\
K1 & Poland, Puławy & "Raba" & 2000 \\
K3 & Poland, Stare Pole & Trifolium sp. & 2000 \\
K10 & Poland, Eabunie & Trifolium sp. & 2000 \\
K18 & Poland, Opatów & Trifolium sp. & 2004 \\
K20 & Poland, Puławy & White clover (T. repens L.) \\
K 99/4 & Poland, Puławy & White clover (T. repens L.) & 2004 \\
K 99/11 & Poland, Puławy & Trifolium sp. & 1998 \\
K 99/12 & Poland, Wielichowo & Trifolium sp. & 1999 \\
K 99/13 & Poland, Wielichowo & Trifolium sp. & 1999 \\
& Poland, Wielichowo & Trifolium sp. & 1999 \\
\hline
\end{tabular}

* Strain was isolated from plants growing in soil contaminated with heavy metals.

\section{2. $P C R$ and sequencing}

For PCR, a small amount of material was taken from a single bacterial colony and transferred to a sterile eppendorf with $20 \mu \mathrm{l}$ of MiliQ water. The samples were thoroughly mixed and $1 \mu \mathrm{l}$ was taken from the mixture for the PCR reaction. The $16 \mathrm{~S}$ rDNA region was amplified using primers: $27 \mathrm{~F}$ (AGAGTTTGATCCTGGCTCAG) and 1492R (GGTTACCTTGTTACGACTT) [4]. The PCR products were sequenced in Genomed S.A (Warsaw, Poland) using the same primers as at the PCR step. The sequences from both primers were assembled in Unipro UGENE 1.25 software [5] and the Blast search has been taken [6].

\subsection{Biolog GEN III}

The study of metabolic activity was performed using the GEN III BIOLOG system method (Biolog Inc., Hayward, CA, USA). The GEN III microplate contains 94 phenotypic tests: 71 carbon source utilization assays and 23 chemical sensitivity assays. Tetrazolium dyes from the wells of the microplate are used to indicate the use of carbon sources or resistance to inhibitory chemicals by microorganisms. The cell suspensions were inoculated into the $134 \mathrm{GEN} \mathrm{III}{ }^{\mathrm{TM}}$ (100 $\mu \mathrm{l}$ per well) and incubated at $25^{\circ} \mathrm{C}$ for 7 days. The intensity of colour development was recorded at $\lambda=590 \mathrm{~nm}$ at $24 \mathrm{~h}$ intervals for a period of $168 \mathrm{~h}$. The results obtained at $168 \mathrm{~h}$ are presented because the most intensive substrate decomposition was observed after this incubation time.

\subsection{Data analysis and visualisation}

Heatmaps were generated using GenIII Omnilog values (data after $168 \mathrm{~h}$ of incubation) with $\mathrm{R}$ software (version 3.5.1, Northern Ave, Boston, USA) and pheatmap package. Similarity trees were constructed using Bray-Curtis cluster analysis with the UPGMA method [7].

Statistical analyses were performed using the packet Statistica.PL ver. 10.0 (StatSoft. Inc., Tulsa, OK, USA). The dendrogram was applying Ward's method clustering and the squared Euclidean distance matrix calculation method [8].

\section{Results}




\subsection{Bacterial species}

PCR products from all the isolates were compared with a size marker and a product with an expected size of about $1500 \mathrm{bp}$ was found (Figure 1). Based on the sequencing of PCR products, we found that all strains belong to one species - Rhizobium leguminosarum with a sequence identity of 97100\% (NCBI GenBank, Table 2) [6].

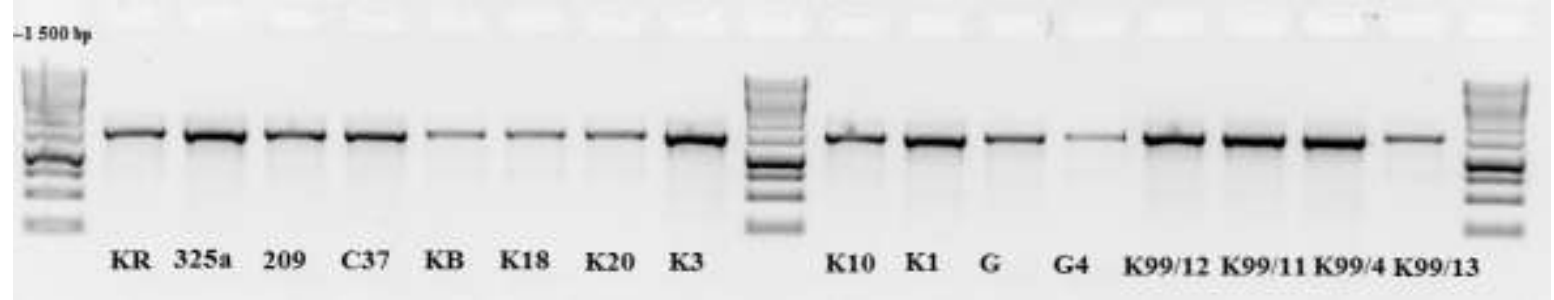

Figure 1. Picture of polyacrylamide gel electrophoresis.

Table 2. The identification of bacteria strains (NCBI GenBank).

\begin{tabular}{clc}
\hline Strain symbol & Closest species & Identity \\
\hline 209 & Rhizobium legiuminosarum & $100 \%$ \\
G & Rhizobium legiuminosarum & $100 \%$ \\
K10 & Rhizobium legiuminosarum & $100 \%$ \\
K99/12 & Rhizobium legiuminosarum & $100 \%$ \\
K99/4 & Rhizobium legiuminosarum & $100 \%$ \\
KR & Rhizobium legiuminosarum & $100 \%$ \\
C37 & Rhizobium legiuminosarum & $99 \%$ \\
325a & Rhizobium legiuminosarum & $99 \%$ \\
G4 & Rhizobium legiuminosarum & $99 \%$ \\
K3 & Rhizobium legiuminosarum & $99 \%$ \\
K99/11 & Rhizobium legiuminosarum & $99 \%$ \\
K99/13 & Rhizobium legiuminosarum & $99 \%$ \\
KB & Rhizobium legiuminosarum & $99 \%$ \\
K1 & Rhizobium legiuminosarum & $98 \%$ \\
K20 & Rhizobium legiuminosarum & $97 \%$ \\
K18 & Rhizobium legiuminosarum & $97 \%$ \\
\hline
\end{tabular}

All sequences are available at the NCBI database under accession number: SUB7603645.

\subsection{Metabolic activity of Rhizobium leguminosarum bacteria}

Based on results the heat maps were made (Figure 2) and the cluster analysis according to Ward's method conducted thus illustrating the diversity of strains in terms of the intensity and pace of the individual compounds consumption (Figure 3). 


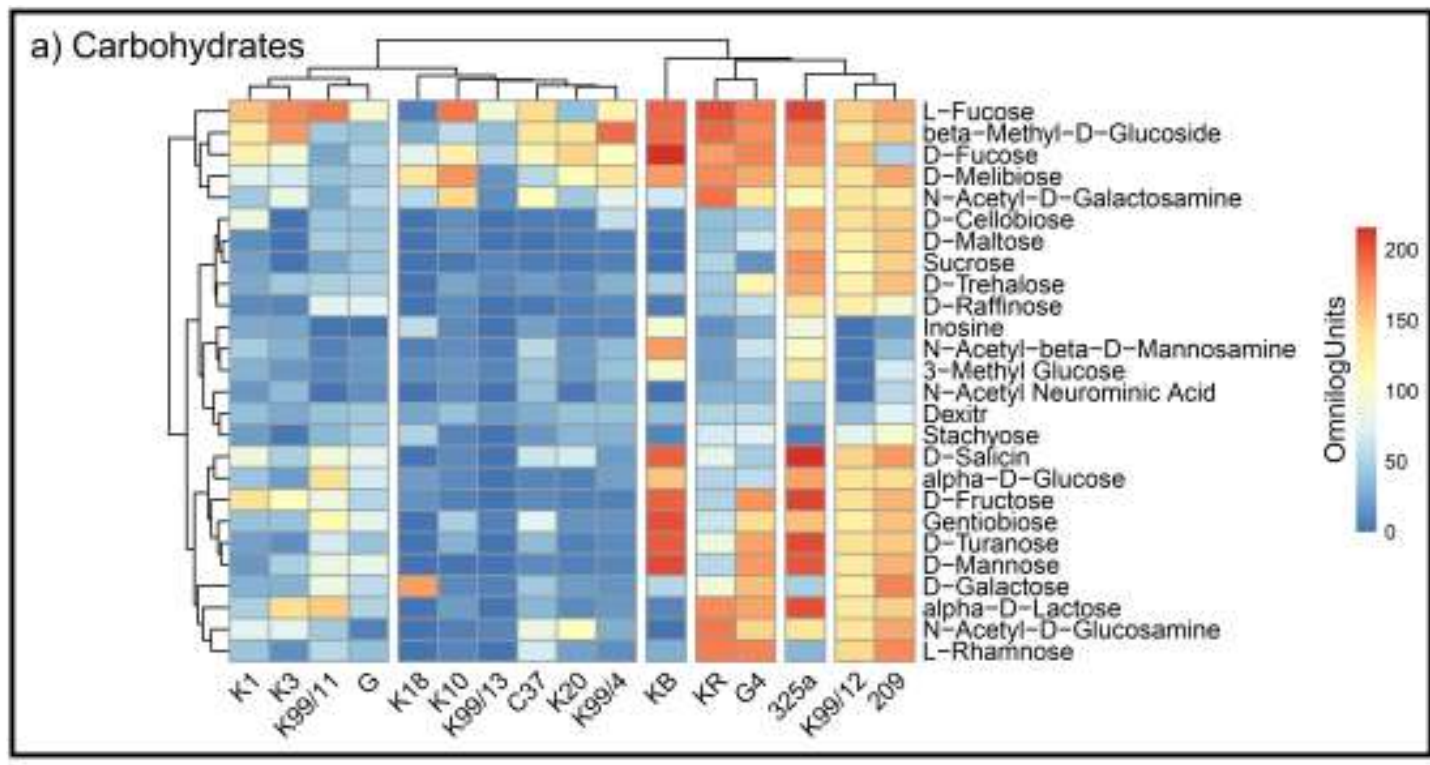

b) Amino acids

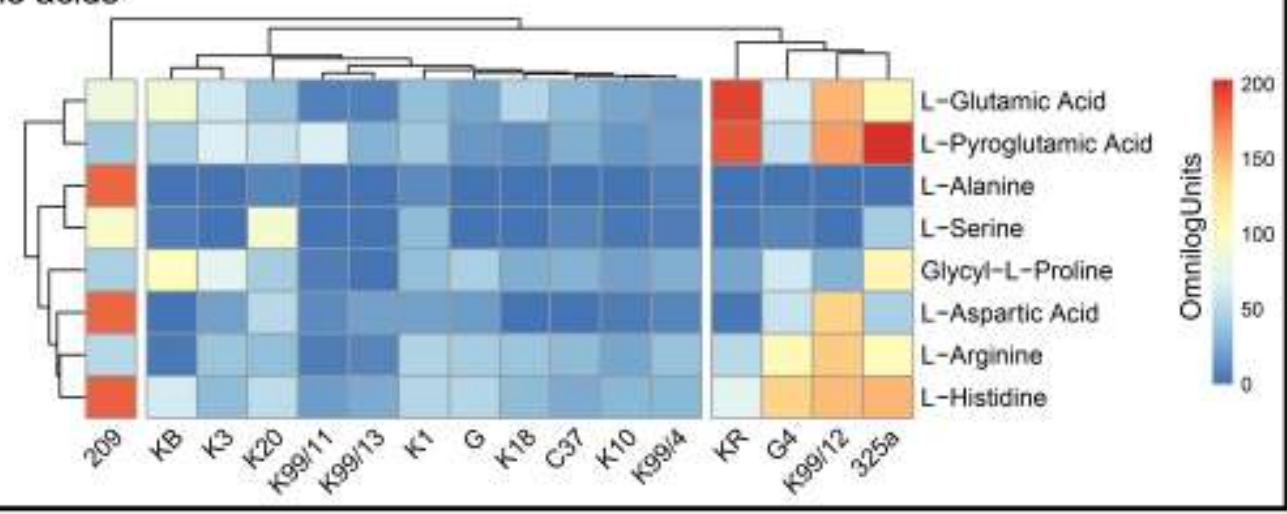

c) Fatty acids

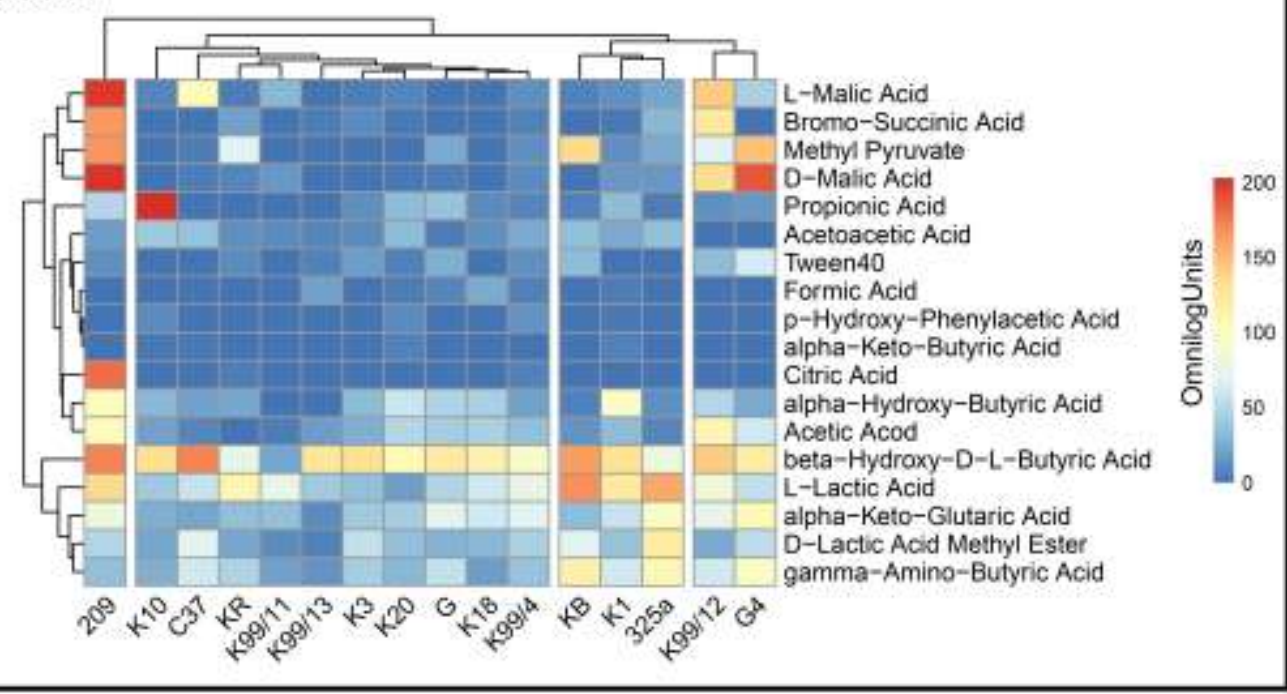

Figure 2. Heatmaps for the carbon utilization patterns of the substrates GEN III grouped into three biochemical groups: (a) carbohydrates, (b) amino acids, (c) fatty acids, by each strain of Rhizobium leguminosarum. Data are shown after 168 hours of incubation. The gradient from light blue to red represents positive utilization. 


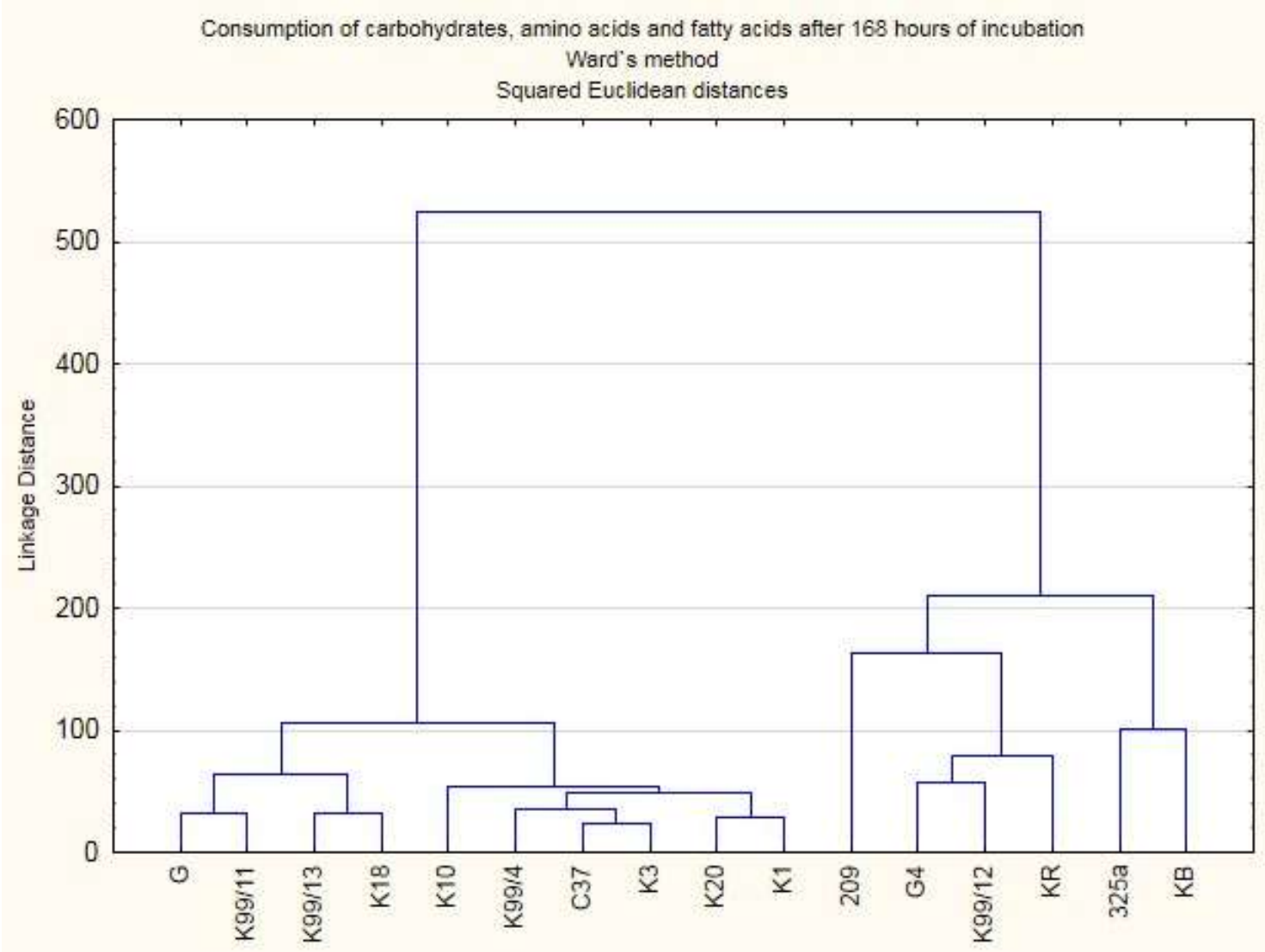

Figure 3. Dendrogram showing division of Rhizobium leguminosarum strains due to the use of carbohydrates, amino acids and fatty acids as a carbon sources after $168 \mathrm{~h}$ incubation.

Metabolism analysis of all R. leguminosarum strains with the use of GEN III ${ }^{\mathrm{TM}}$ plates showed that carbohydrates $(\mathrm{CH})$ were the most intensively utilised group of substrates. Between the Rhizobium leguminosarum strains, there are metabolic differences in terms of the studied features (Figure 2). That may indicate the adaptive capacity of microorganisms to the environmental conditions in which they currently live. Based on the cluster analysis, 3 groups of microorganisms were isolated in terms of the intensity of decomposition of the tested compounds (Figure 3). The most active strains in terms of using as a carbon source all three types of compounds are strains 209, K99/12, 325a and G4.

\section{Conclusions}

In conclusion, it can be stated that, between the Rhizobium leguminosarum strains, there are metabolic differences in terms of the studied features. That may indicate the adaptive capacity of microorganisms to the environmental conditions in which they currently live.

Author Contributions: K.G. and A.G. conceived and designed the experiments; K.G., K.F. and J.G. performed the experiments and analysed the data; K.G. and K.F. wrote the paper

Funding: The research was partially funded by the Ministry of Science and Higher Education, research task: "Determination of the effect of co-inoculation of clover (Trifolium pretense L.) with Azospirillum spp. and Rhizobium spp. for the growth and nodulation of plants under conditions of contamination by polycyclic aromatic hydrocarbons"/2016 and the frames of Task 1.4. Multi - Annual Programme IUNG - PIB (2016-2020).

Conflicts of Interest: The authors declare no conflict of interest. The founding sponsors had no role in the design of the study; in the collection, analyses, or interpretation of data; in the writing of the manuscript, and in the decision to publish the results.

\section{References}


1. Stasiak, G.; Mazur, A.; Koper, P.; Żebracki, K.; Skorupska, A. Symbiosis of rhizobia with legume plants (Fabaceae). Postep. Mikrobiol. 2016, 55, 289-299.

2. Kereszt, A.; Mergaert, P.; Kondorosi, E. Bacteroid development in legume nodules: Evolution of mutual benefit or of sacrificial victims? Mol. Plant-Microbe Interact. 2011, 24, 1300-1309.

3. Oke, V.; Long, S.R. Bacteroid formation in the Rhizobium-legume symbiosis. Curr. Opin. Microbiol. 1999, 2 , 641-646.

4. Weisburg, W.G.; Barns, S.M.; Pelletier, D.A.; Lane, D.J. 16S Ribosomal DNA Amplification for Phylogenetic Study. J. Bacteriol. 1991, 173, 697-703.

5. Okonechnikov, K.; Golosova, O.; Fursov, M.; UGENE team Unipro UGENE: a unified bioinformatics toolkit. Bioinformatics 2012, 28, 1166-1167, doi:10.1093/bioinformatics/bts091.

6. Blast NCBI Available online: https://blast.ncbi.nlm.nih.gov/Blast.cgi.

7. McMurdie, P.J.; Holmes, S. phyloseq: An R Package for Reproducible Interactive Analysis and Graphics of Microbiome Census Data. PLoS One 2013, 8, e61217, doi:10.1371/journal.pone.0061217.

8. Ward, J.H. Hierarchical Grouping to Optimize an Objective Function. J. Am. Stat. Assoc. 1963, 58, 236-244, doi:10.1080/01621459.1963.10500845.

Publisher's Note: MDPI stays neutral with regard to jurisdictional claims in published maps and institutional affiliations.

(C) 2020 by the authors. Submitted for possible open access publication under the terms and conditions of the Creative Commons Attribution (CC BY) license (http://creativecommons.org/licenses/by/4.0/). 